\title{
Article \\ Comparison of the Genetic Features Involved in Bacillus subtilis Biofilm Formation Using Multi-Culturing Approaches
}

\author{
Yasmine Dergham ${ }^{1,2}$, Pilar Sanchez-Vizuete ${ }^{1}$, Dominique Le Coq ${ }^{1,3}$, Julien Deschamps ${ }^{1}$, Arnaud Bridier ${ }^{4}$, \\ Kassem Hamze ${ }^{2}$ and Romain Briandet $1, *$ (D)
}

\section{check for}

updates

Citation: Dergham, Y.;

Sanchez-Vizuete, P.; Le Coq, D.;

Deschamps, J.; Bridier, A.; Hamze, K.;

Briandet, R. Comparison of the

Genetic Features Involved in Bacillus

subtilis Biofilm Formation Using

Multi-Culturing Approaches.

Microorganisms 2021, 9, 633.

https://doi.org/10.3390/

microorganisms 9030633

Academic Editor: Imrich Barák

Received: 19 February 2021

Accepted: 16 March 2021

Published: 18 March 2021

Publisher's Note: MDPI stays neutral with regard to jurisdictional claims in published maps and institutional affiliations.

Copyright: (c) 2021 by the authors. Licensee MDPI, Basel, Switzerland. This article is an open access article distributed under the terms and conditions of the Creative Commons Attribution (CC BY) license (https:// creativecommons.org/licenses/by/ $4.0 /)$.
1 Micalis Institute, INRAE, AgroParisTech, Université Paris-Saclay, 78350 Jouy-en-Josas, France; yasmin.dorghamova-dergham@inrae.fr (Y.D.); pilarsanviz@gmail.com (P.S.-V.); dominique.le-coq@inrae.fr (D.L.C.); julien.deschamps@inrae.fr (J.D.)

2 Faculty of Science, Lebanese University, 1003 Beirut, Lebanon; kassem.hamze@ul.edu.lb

3 Centre National de la Recherche Scientifique (CNRS), Micalis Institute, INRAE, AgroParisTech, Université Paris-Saclay, 78350 Jouy-en-Josas, France

4 Fougères Laboratory, Antibiotics, Biocides, Residues and Resistance Unit, Anses, 35300 Fougères, France; arnaud.bridier@anses.fr

* Correspondence: romain.briandet@inrae.fr

\begin{abstract}
Surface-associated multicellular assemblage is an important bacterial trait to withstand harsh environmental conditions. Bacillus subtilis is one of the most studied Gram-positive bacteria, serving as a model for the study of genetic pathways involved in the different steps of 3D biofilm formation. B. subtilis biofilm studies have mainly focused on pellicle formation at the air-liquid interface or complex macrocolonies formed on nutritive agar. However, only few studies focus on the genetic features of $B$. subtilis submerged biofilm formation and their link with other multicellular models at the air interface. NDmed, an undomesticated B. subtilis strain isolated from a hospital, has demonstrated the ability to produce highly structured immersed biofilms when compared to strains classically used for studying B. subtilis biofilms. In this contribution, we have conducted a multi-culturing comparison (between macrocolony, swarming, pellicle, and submerged biofilm) of B. subtilis multicellular communities using the NDmed strain and mutated derivatives for genes shown to be required for motility and biofilm formation in pellicle and macrocolony models. For the 15 mutated NDmed strains studied, all showed an altered phenotype for at least one of the different culture laboratory assays. Mutation of genes involved in matrix production (i.e., $\operatorname{tas} A$, eps $A-O$, cap, ypq $P$ ) caused a negative impact on all biofilm phenotypes but favored swarming motility on semi-solid surfaces. Mutation of $b s l A$, a gene coding for an amphiphilic protein, affected the stability of the pellicle at the air-liquid interface with no impact on the submerged biofilm model. Moreover, mutation of $l y t F$, an autolysin gene required for cell separation, had a greater effect on the submerged biofilm model than that formed at aerial level, opposite to the observation for $l y t A B C$ mutant. In addition, $B$. subtilis NDmed with $\sin R$ mutation formed wrinkled macrocolony, less than that formed by the wild type, but was unable to form neither thick pellicle nor structured submerged biofilm. The results are discussed in terms of the relevancy to determine whether genes involved in colony and pellicle formation also govern submerged biofilm formation, by regarding the specificities in each model.
\end{abstract}

Keywords: Bacillus subtilis; NDmed; biofilm; pellicle; complex macrocolonies; swarming; confocal laser scanning microscopy (CLSM)

\section{Introduction}

Bacteria in nature frequently exist in communities that display complex social behavior, which involves intercellular signaling to permit survival and dissemination in a wide variety of habitats [1]. Even within a pure culture biofilm, where cells are genetically 
identical, different patterns of gene expression co-exist and therefore produce subpopulations of functionally distinct cell types [2]. Surface-associated biofilm develops in a sequential process in which sessile bacterial cells secrete extracellular matrix and aggregate as structured multicellular groups [3,4]. In nature, microbial biofilms participate in many biogeochemical cycling processes for most elements in water, soil, sediments, and subsurface environments [5]. In addition, utilization of microbial antagonists as biological control agents is a promising biotechnological alternative to the use of pesticides, which often accumulate in plants and end up by affecting humans in a direct or indirect way [6] However, in terms of public health and with the medical science progress, more and more medical devices and/or artificial organs are being applied in the treatment of human diseases. As a consequence, biofilm-associated infections has become also frequent. It has been estimated that many bacterial infections in human are correlated with biofilm formation and are associated with the indwelling medical devices (such as catheters or needles) [7].

Over the last decades, Bacillus subtilis, a Gram-positive, motile, spore-forming bacterium has served as a model organism for molecular studies on biofilm formation [5]. These studies were mainly based on the development of complex macrocolonies on the agar-air interface, or floating pellicle at the air-liquid interface, and only few on submerged biofilms [8-14]. These models allowed highlighting that the transition from motile to sessile biofilm lifestyle, and vice versa, is controlled by complex genes regulatory networks. Four pairs of global regulators-the Spo0A/AbrB, SinI/SinR, SlrR/SlrA, and DegS/DegUhave been shown to play major roles, directly and indirectly, on both the formation and development of complex multicellular communities and on expression of the motilityinvolved genes $[8,12,15-20]$. Flagella required for motility are partly encoded by the fla/che operon, which, in addition to flagellar genes, includes chemotaxis genes and the sig $D$ gene. In turn, the sigma $\mathrm{D}$ factor has been shown to direct transcription of other flagellar genes outside the fla/che operon (i.e., hag gene and other SigD-dependent motility genes) and genes involved in autolytic enzymes synthesis $(l y t C, l y t D$, and $l y t F)$ that mediate the separation of sister cells after cell division [21-24]. On the other hand, Spo0A phosphorylation represses two negative biofilm formation regulators, AbrB and SinR, therefore leading to expression of genes involved in the synthesis of biofilm matrix (polysaccharide synthesis by eps $A-O$, amyloid like fiber Tas A encoded by the tapA-sipW-tas $A$ operon, and the amphiphilic matrix protein produced by $b s l A)[2,25]$.

In specific conditions, cells from a bacterial colony can become highly motile and migrate over the substrate with specific collective patterns, a process known as swarming [4]. Swarming - a remarkable example of cooperative behavior in bacteria-is a mass, coordinated, and rapid migration (2 to $10 \mathrm{~mm} / \mathrm{hr}$ ) of cells on a surface [26]. In B. subtilis, this developmental process is observed on semi-solid agar $(0.6 \%-1 \%$ agar) and has been shown to be completely dependent on flagella and surfactin production [26-29].

In 2001, Hamon and Lazazzera have shown that B. subtilis has the ability to adhere to abiotic surfaces and form structured biofilms [8], which have grabbed biofilm researches to reconsider the importance of the immersed surface-associated biofilm model for this species. In this context, architectural comparative submerged biofilm studies performed on various $B$. subtilis strains from different origins, including NCIB3610 and 168 reference strains, have revealed an undomesticated B. subtilis NDmed strain as able to form the highest submerged biofilm biovolume [11,13].

The NDmed strain, isolated from a hospital endoscope washer-disinfector was found to resist to the action of peracetic acid (an oxidizing agent commonly used in formulations used for the endoscope disinfection) and to have the ability to protect the pathogen Staphylococcus aureus in mixed biofilms [30,31]. By the use of confocal and electronic microscopy techniques, it has been shown that the hyper-resistant phenotype was related to the complex architectural biofilm formed and to the large amount of extracellular matrix produced that could prevent the diffusion-reaction of oxidizing agents [30]. Moreover, further genetic comparison between NDmed and other B. subtilis reference strains pinpointed that the 
ypqP gene (renamed spsM [32]), potentially involved in the synthesis of polysaccharide, was involved indirectly in this resistance by participating to the strong spatial organization of the B. subtilis NDmed biofilms, both at air and liquid interfaces [13]. This gene is disrupted by the SP $\beta$ prophage in both B. subtilis NCIB3610 and 168 strains [13]. These new observations suggested that interfaces between surfaces and liquids could, as for most other bacteria, be a relevant biotope for B. subtilis biofilm.

Our knowledge for the molecular mechanisms controlling the formation and the behavior of $B$. subtilis 3D communities is still limited. In this contribution, B. subtilis NCIB3610 and 168 strains were compared to NDmed in different laboratory culture conditions. Moreover, 15 mutants derived from the NDmed strain and defective in genes previously described as triggering biofilm formation were compared through a multiculturing approach using four multicellular models, at the interface with air (solid agar, semi-solid agar, liquid medium) or at the interface between a solid surface (polystyrene) and a liquid medium, submerged model. Thus, this provided a global view over the different biofilm laboratory assays used to study the effect of gene mutation on both motility and biofilm formation in B. subtilis wild type.

\section{Materials and Methods}

\subsection{Bacterial Strains and Growth Conditions}

All bacterial strains and mutants used in this study are listed in Table 1 . The B. subtilis NDmed derivatives mutated in various genes were obtained by transformation with chromosomal DNA extracted from strains carrying the corresponding different alleles of interest marked with a suitable antibiotic resistance cassette. Transforming chromosomal DNA was extracted according to the method of Marmur [33], and transformation of $B$. subtilis was performed according to the method of Anagnostopoulos and Spizizen [34], including the use of the MGI and MGII media of Borenstein and Ephrati-Elizur [35]. Transformants were selected on Lysogeny Broth (LB) plates supplemented with the relevant antibiotic at the following concentrations: spectinomycin, $100 \mu \mathrm{g} \mathrm{ml}^{-1}$; chloramphenicol, $4 \mu \mathrm{g} \mathrm{ml}^{-1}$; erythromycin, $0.5 \mu \mathrm{g} \mathrm{ml}^{-1}$; tetracycline, $10 \mu \mathrm{g} \mathrm{ml}^{-1}$; neomycin and kanamycin, $8 \mu \mathrm{g} \mathrm{ml}^{-1}$. Before each experiment, cells were subcultured in Tryptone Soya Broth (TSB, BioMérieux, France; $\mathrm{pH}$ 7.2) and supplemented with antibiotics when necessary. For biofilm formation, bacteria were grown in TSB at $30{ }^{\circ} \mathrm{C}$ for $8 \mathrm{~h}$ with agitation, then diluted $1 / 100$ in $10 \mathrm{~mL}$ TSB incubated overnight at $30^{\circ} \mathrm{C}$. This culture was then used to grow biofilms on different assays. Bacteria for swarming experiments were grown with agitation at $37{ }^{\circ} \mathrm{C}$ in synthetic B-medium composed of (all final concentrations; pH 7.2 ) $15 \mathrm{mM}$ $\left(\mathrm{NH}_{4}\right)_{2} \mathrm{SO}_{4}, 8 \mathrm{mM} \mathrm{MgSO} 4.7 \mathrm{H}_{2} \mathrm{O}, 27 \mathrm{mM} \mathrm{KCl}, 7 \mathrm{mM}$ sodium citrate. $2 \mathrm{H}_{2} \mathrm{O}, 50 \mathrm{mM}$ Tris $/ \mathrm{HCl}$ (pH 7.5), and $2 \mathrm{mM} \mathrm{CaCl}_{2} \cdot 2 \mathrm{H}_{2} \mathrm{O}, 1 \mu \mathrm{M} \mathrm{FeSO}_{4} .7 \mathrm{H}_{2} \mathrm{O}, 10 \mu \mathrm{M} \mathrm{MnSO}_{4} .4 \mathrm{H}_{2} \mathrm{O}, 0.6 \mathrm{mM} \mathrm{KH}_{2} \mathrm{PO}_{4}$, $4.5 \mathrm{mM}$ glutamic acid ( $\mathrm{pH} 8$ ), $862 \mu \mathrm{M}$ lysine, $784 \mu \mathrm{M}$ tryptophan, $1 \mathrm{mM}$ threonine and $0.5 \%$ glucose were added before use [36]. Antibiotics were added to bacterial cultures when needed.

Table 1. Bacillus subtilis strains used in this study.

\begin{tabular}{|c|c|c|}
\hline Strain & Genotype or Isolation Source & Construction $^{\text {a }}$ or Reference \\
\hline NDmed & $\begin{array}{l}\text { Undomesticated, isolated from endoscope } \\
\text { washer-disinfectors }\end{array}$ & [31] \\
\hline NCIB3610 & Natural isolate, less domesticated & [37] \\
\hline 168 & trpC2 (domesticated strain) & [37] \\
\hline GM3248 & NDmed $\triangle y p q P::$ kan & {$[13]$} \\
\hline GM3533 & NDmed $\Delta \sin R:: \mathrm{cm}$ & Tf NDmed/DNA ABS840 [38] \\
\hline GM3535 & NDmed $\triangle$ epsA-O:: tet & $\begin{array}{c}\text { Tf NDmed/DNA GM3532 [NCIB3610, } \Delta \text { tasA:: kan, } \\
\Delta e p s A-O:: \text { tet] ( our lab collection) }\end{array}$ \\
\hline GM3539 & NDmed $\Delta \sin I::$ kan & Tf NDmed/DNA ABS803 [39] \\
\hline GM3545 & NDmed $\Delta$ cap:: pKPSd/ cm & $\begin{array}{l}\text { Tf NDmed/DNA GM3543 [NCIB3610 } \Delta c a p:: \text { pKPSd / cm] } \\
\text { (our lab collection) }\end{array}$ \\
\hline
\end{tabular}


Table 1. Cont.

\begin{tabular}{ccc}
\hline Strain & Genotype or Isolation Source & Construction ${ }^{\text {a }}$ or Reference \\
\hline GM3555 & NDmed $\Delta a b r B:: \mathrm{cm}$ & Tf NDmed/DNA MM1717 [40] \\
GM3559 & NDmed $\Delta d e g U::$ neo & Tf NDmed/DNA GM719 [41] \\
GM3561 & NDmed $\Delta b s l A:: \mathrm{cm}$ & Tf NDmed/DNA NRS2097 [20] \\
GM3602 & NDmed $\Delta l y t F:$ spec & Tf NDmed/DNA NRS3295 [42] \\
GM3611 & NDmed $\Delta l y t A B C::$ kan & Tf NDmed/DNA NRS3295 [42] \\
GM3614 & NDmed $\Delta t a s A::$ kan & Tf NDmed/DNA GM3532 [NCIB3610, $\Delta t a s A::$ kan, \\
GM3618 & NDmed $\Delta s l r R::$ spec & $\Delta e p s A-O::$ tet] ( our lab collection) \\
GM3619 & NDmed $\Delta s r f A A::$ ery & Tf NDmed/DNA GM3598 [NCIB3610 $\Delta s l r R::$ spec] (our \\
lab collection)
\end{tabular}

${ }^{\text {a }}$ TF NDmed/DNA stands for transformation of NDmed by chromosomal DNA of indicated strains.

\subsection{Submerged Biofilm Developmental Assays}

Submerged biofilms were grown on the surface of polystyrene 96-well microtiter plates with a $\mu$ clear $^{\circledR}$ base (Greiner Bio-one, France) enabling high-resolution fluorescence imaging as previously described [44]. An amount of $200 \mu \mathrm{L}$ of an overnight culture in TSB (adjusted to an OD $600 \mathrm{~nm}$ of 0.02) was added in each well. The microtiter plate was then incubated at $30{ }^{\circ} \mathrm{C}$ for $90 \mathrm{~min}$ to allow the bacteria to adhere to the bottom of the wells. Wells were then rinsed with TSB to eliminate non-adherent bacteria and refilled with $200 \mu \mathrm{L}$ of sterile TSB. The plates were incubated at $30^{\circ} \mathrm{C}$ for $24 \mathrm{~h}$, and $5 \mu \mathrm{M}$ of the cell permeant nucleic acid dye SYTO 9 (diluted 1:1000 in TSB from a SYTO 9 stock solution at $5 \mathrm{mM}$ in DMSO; Invitrogen, France) were added to the $200 \mu \mathrm{L}$ culture, obtain green fluorescent bacteria. For each strain, at least 9 to 15 wells were analyzed independently.

\subsection{Macrocolony Experimental Conditions}

For colony architectural formation, $3 \mu \mathrm{L}$ of an overnight culture in TSB were inoculated on $1.5 \%$ Tryptone Soya Agar (TSA) with $40 \mu \mathrm{g} / \mathrm{mL}$ Congo Red (Sigma-Aldrich, St. Quentin Fallavier, France) and $20 \mu \mathrm{g} / \mathrm{mL}$ Coomassie Brilliant Blue (Sigma-Aldrich, St. Quentin Fallavier, France). Congo Red has been shown to bind extracellular matrix components and allows to compare the ability of different bacterial strains, including B. subtilis, which binds to amyloidic proteins [45,46]. The Coomassie Blue has a high affinity to bind proteins and is commonly used to detect, visualize, and quantify proteins separated on polyacrylamide gels $[47,48]$. The plates were then incubated at $30^{\circ} \mathrm{C}$ for 6 days. Digital images of the colonies on the plates were taken using a Canon EOS 80D with $24 \mathrm{MP}(6000 \times 4000$ pixels) . Macrocolony experiments were performed three to five times independently.

\subsection{Swarming Experiment Conditions}

Cultures for the swarm inoculum were prepared in $10 \mathrm{~mL}$ B-medium inoculated with a single colony and shaken overnight at $37^{\circ} \mathrm{C}$. The culture was then diluted to an $\mathrm{OD}_{600 \mathrm{~nm}}$ of approximately 0.1 and grown until it reached an $\mathrm{OD}_{600 \mathrm{~nm}}$ of approximately 0.2 . This procedure was repeated twice and finally the culture was grown to T4 $(4 \mathrm{~h}$ after the transition from exponential growth). The $\mathrm{OD}_{600 \mathrm{~nm}}$ was measured and the culture was diluted, and $2 \mu \mathrm{L}$ of diluted bacterial culture $\left(10^{4} \mathrm{CFU}\right)$ were inoculated at the center of B-medium agar plate and incubated for $24 \mathrm{~h}$ at $30{ }^{\circ} \mathrm{C}$ with $50 \%$ relative humidity. Plates ( $9 \mathrm{~cm}$ diameter) containing $25 \mathrm{~mL}$ agar medium ( $0.7 \%$ agar) were prepared $1 \mathrm{~h}$ before inoculation and dried with lids open for $5 \mathrm{~min}$ before inoculation. Pictures were taken by a digital Nikon Coolpix P100 (10 MP) camera. Swarming experiments were repeated three to five times independently. 


\subsection{Pellicle Experiments}

After an overnight culture in TSB at $30{ }^{\circ} \mathrm{C}, 10 \mu \mathrm{L}$ of the bacterial suspension were used to inoculate $2 \mathrm{~mL}$ of TSB in 24-well plates (TPP, Trasadingen, Switzerland). Plates were then incubated at $30^{\circ} \mathrm{C}$ for $24 \mathrm{~h}$. Digital images of the pellicles were taken using a digital Nikon Coolpix P100 (10 MP) camera. This experiment was repeated three up to five times independently for each condition.

\subsection{Non-Invasive Confocal Laser Scanning Microscopy (CLSM) of Submerged Biofilms}

Immersed biofilms were observed using a Leica SP8 AOBS inverter confocal laser scanning microscope (CLSM, LEICA Microsystems, Wetzlar, Germany) at the INRAE MIMA2 platform (www6.jouy.inra.fr/mima2_eng/ accessed on 1 December 2020). For observation, strains were tagged fluorescently in green with SYTO 9 (1:1000 dilution in TSB), a nucleic acid marker. After $20 \mathrm{~min}$ of incubation in the dark at $30^{\circ} \mathrm{C}$ to enable fluorescent labeling of the bacteria, plates were then mounted on the motorized stage of the confocal microscope. Biofilms on the bottom of the wells were scanned using a HC PL APO CS2 63x/1.2 water immersion objective lens. SYTO 9 excitation was performed at $488 \mathrm{~nm}$ with an argon laser, and the emitted fluorescence was recorded within the range $500-600 \mathrm{~nm}$ on hybrids detectors. The 3D (xyz) acquisitions were performed $(512 \times 512$ pixels, pixel size $0.361 \mu \mathrm{m}$, 1 image every $z=1 \mu \mathrm{m}$ with a scan speed of $600 \mathrm{~Hz}$ ). Easy 3D projections were constructed from Z-series images using IMARIS v9.0 software (Bitplane AG, Zurich, Switzerland). Biofilms biomass was estimated through extraction of the biofilm biovolume (in $\mu \mathrm{m}^{3} / \mu \mathrm{m}^{2}$ ) after isosurfaces automatic detection using the IMARIS quantification module from a minimum of twenty confocal image z-series.

\subsection{Statistical Analysis}

One-way ANOVA was performed using GraphPad Prism 8 software (GraphPad, CA, USA). Significance was defined as a $p$ value associated with a Fisher test value lower than 0.05 .

\section{Results and Discussion}

\subsection{Bacillus Subtilis NDmed forms Highly Structured Biofilms Compared to the NCIB3610 and} 168 Strains

In the last decades, NCIB3610 has been widely used as a model for the "wild type" of B. subtilis. This strain has been shown to form more elaborate and robust biofilm communities when compared to the domesticated laboratory stain 168 [49,50]. However, in both the NCIB3610 and 168 strains, the ypqP gene is disrupted by the SP $\beta$ prophage, contrary to several sequenced natural isolates of $B$. subtilis [13]. This gene has been shown to be involved in the strong spatial organization of biofilms of the undomesticated B. subtilis NDmed strain, both at air and liquid interfaces [13]. In this study, a phenotypical characterization of NDmed grown under different laboratory culture conditions was performed, in comparison with the classical reference strains NCIB3610 and 168.

Macrocolonies of these strains were observed after being grown for 6 days on indicator plates containing both Congo Red (labeling amyloidic proteinaceous compounds in B. subtilis biofilm matrix) and Coomassie blue (proteinaceous matrix counterstain) [46,47]. As shown in Figure 1, the NDmed strain formed a highly structured and more compact macrocolony, contrary to the NCIB3610 and 168 strains that formed flat macrocolonies without or with only very fine wrinkles. In addition, the NDmed macrocolony was more intensely stained by the Congo Red, indicating a higher amount of exopolymeric substances and proteins produced compared to the two other strains.

As the biofilms formed by these three strains had such profound architectural differences, we wondered whether they might also present marked differences in another structured multicellular behavior i.e., swarming. Hence, to better visualize differences between them, semi-solid plates (swarming plates) were used as a 2D model to view bacterial surface colonization initiating from a macrocolony. Dendritic swarming pattern 
of B. subtilis was previously best characterized on a synthetic fully defined medium (Bmedium) with optimized nutrient and temperature conditions [28]. Figure 1 shows the swarming patterns obtained on the synthetic B-medium ( $0.7 \%$ agar) after $24 \mathrm{~h}$ of incubation at $30^{\circ} \mathrm{C}$ for the studied B. subtilis strains. Obviously, both NDmed and NCIB3610 showed swarming on B-medium but with varied dendritic patterns. NCIB3610 displayed a thin highly complex dendritic swarming pattern that spread all over the plate within $24 \mathrm{~h}$ of incubation, whereas NDmed swarmed with a thick countable less spread dendritic pattern. The mother colony of the NDmed appears to be highly structured with slimy texture when disrupted mechanically by a loop. On the other hand, a less structured widely spread mother colony was formed by NCIB3610, suggesting that less extracellular polymeric substances are produced in this strain compared to the NDmed strain. The mother colony in a swarm for both NDmed and NCIB3610 closely resembles the structural architecture of the macrocolonies formed. Consistent with previous observation, the 168 B. subtilis strain failed to swarm on this synthetic medium, essentially because of a frameshift mutation in the $s f p$ gene, required for the surfactin biosynthesis that facilitates the migration over the surface by reducing the surface tension [27].

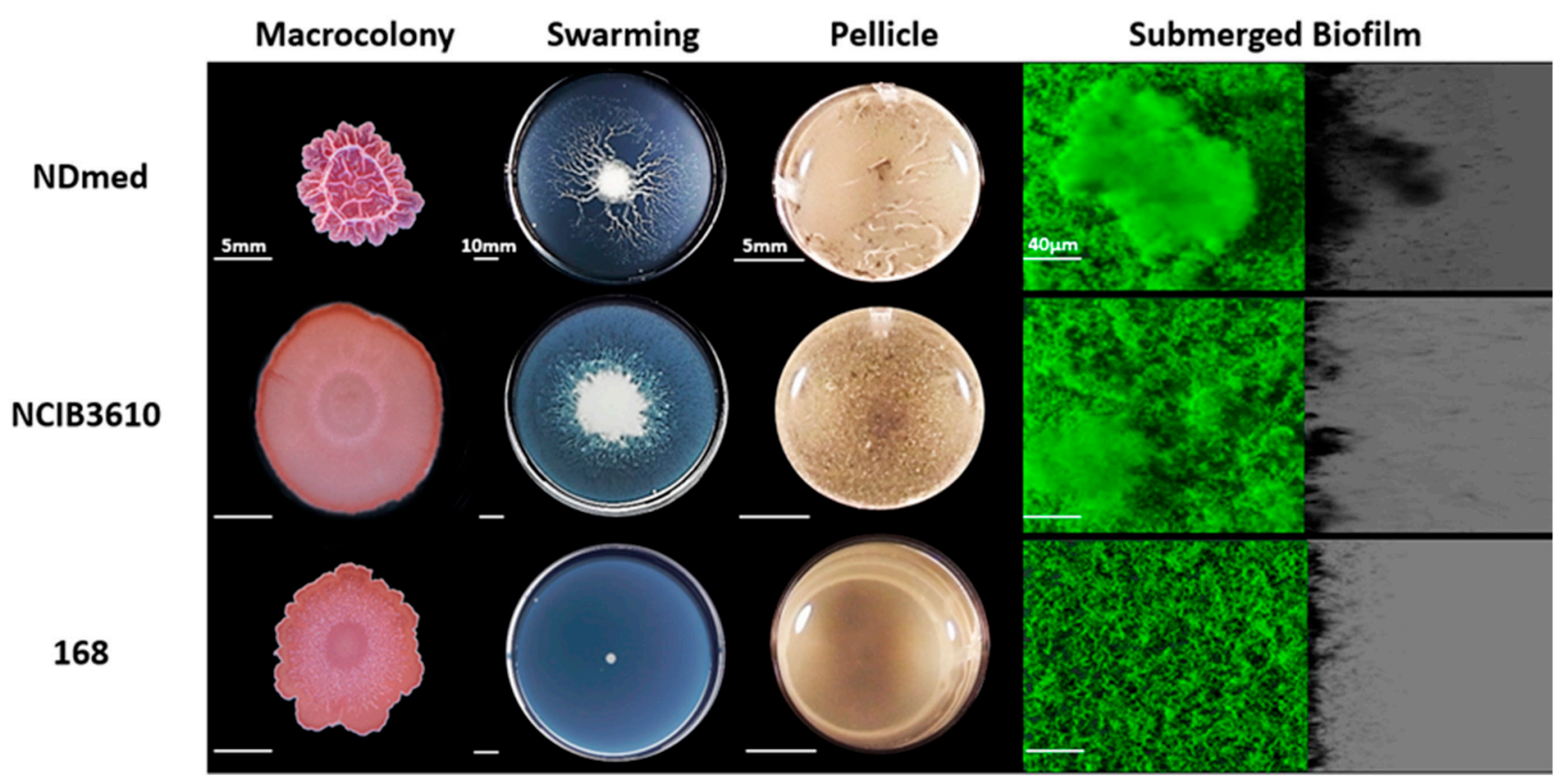

Figure 1. Comparative phenotype for B. subtilis strains on different laboratory assays. Macrocolonies grown on $1.5 \%$ TSA for 6 days at $30^{\circ} \mathrm{C}$ after a central spot of $3 \mu \mathrm{L}$ of an overnight bacterial culture in TSB (scale bars $5 \mathrm{~mm}$ ). $0.7 \%$ of B-synthetic medium is used for swarming plates ( $9 \mathrm{~cm}$ diameter) that are incubated for $24 \mathrm{~h}$ at $30^{\circ} \mathrm{C}$ (scale bars represent $10 \mathrm{~mm}$ ). For pellicles, bacterial cells have been cultured in a 24-well plate with TSB for $24 \mathrm{~h}$ at $30^{\circ} \mathrm{C}$ (scale bars 5 mm). Macrocolony, swarming, and pellicle images are representative for the majority of the phenotype from at least three replicates for each strain, which reveal variation for the surface architecture. In a 96 well microplate system, immersed biofilms are labeled by SYTO 9 after $24 \mathrm{~h}$ of incubation at $30^{\circ} \mathrm{C}$. The shadow on the right represents the virtual lateral shadow projection of the submerged biofilm (scale bars represent $40 \mu \mathrm{m}$ ).

Other models of biofilm are formed in liquid cultures, either at the air-liquid interface (pellicle) or as submerged biofilms at the solid-liquid interface [8,10-12]. To characterize the ability of $B$. subtilis to adhere and to form submerged multicellular communities on surface, CLSM has been used to acquire confocal stack images for the submerged biofilms, from which an Easy-3D reconstruction by the IMARIS software could reveal the threedimensional structure with a lateral virtual shadow projection. As shown in Figure 1, and in accordance with previous reports, B. subtilis NDmed formed well-structured air-liquid biofilm (pellicle) and highly spatially organized submerged biofilm at the solid-liquid interface $[11,13,30]$. 
NCIB3610 strain did not form a thick pellicle within $24 \mathrm{~h}$ of incubation at $30{ }^{\circ} \mathrm{C}$ but produced well-structured biofilms (with a biovolume of $11 \mu \mathrm{m}^{3} / \mu \mathrm{m}^{2}$, significantly smaller than the $14 \mu \mathrm{m}^{3} / \mu \mathrm{m}^{2}$ biovolume formed by the NDmed, $\left.p<0.05\right)$. The 168 strain, as previously been observed [11], was unable to form a pellicle in these conditions and displayed only a much less dense submerged biofilm (with a $6 \mu \mathrm{m}^{3} / \mu \mathrm{m}^{2}$ biovolume) in comparison with the two other B. subtilis strains $(p<0.05)$.

In comparison between the three B. subtilis strains studied here, NDmed displayed complex architectural biofilm formation on/in both solid and liquid medium, and had the ability to swarm rather efficiently.

\subsection{Mutants Affected in Matrix-Producing Components Fail to Form Well-Firmed Surface Cohesive Biofilms}

In order to determine whether the genes involved in B. subtilis colony and pellicle formation also govern submerged biofilm formation, we constructed a set of derivative mutants of the NDmed strain and analyzed the corresponding phenotypes in the different biofilm models.

Extracellular matrix, mainly composed of polymeric substances, is essential for the biofilm structural formation. In $B$. subtilis, the amyloid-like fiber TasA encoded by the tap $A$-sipW-tas $A$ operon, and the polysaccharides synthesized by the products of the eps $A-O$ operon are mainly responsible for the synthesis of biofilm matrix, which bundles cells together and maintains their stability [2,46,49,51,52]. In addition, the BslA protein exhibits amphiphilic properties by forming a hydrophobic layer at the air interface [53] and activates the formation of complex colony development and pellicle formation [20,54]. Poly- $\gamma-$ glutamate ( $\gamma$-PGA), a secreted polymeric substance that accumulates in the culture media like the biofilm matrix [9] and in the capsule, is synthesized by the enzymes encoded by the cap operon. Recently it has been shown that in many tested environmental B. subtilis isolates $\gamma$-PGA production contributed to the complex morphology and robustness by enhancing cell-surface interactions of the colony biofilms [55]. The ypqP gene in both B. subtilis strains 168 and NCIB3610 is disrupted by the SP $\beta$ prophage, whose excision during sporulation phase reconstitutes a functional $y p q P$ gene allowing addition of polysaccharides to the spore envelope [32]. In the undomesticated NDmed strain, ypqP non-disrupted by the SP $\beta$ prophage, has been identified as a requirement for the spatial biofilm organization [13].

Figure 2 shows the effect of matrix gene mutation on different laboratory culture assays. Macrocolonies formed by tas A, epsA-0, bslA, cap, and ypqP mutants on TSA agar medium were flat contrary to the highly structured and wrinkled wild type NDmed colony (Figure 2). Interestingly, the tas $A$ mutant was the least stained, by proteinaceous dyes, indicating a drastic negative effect of the corresponding mutation on extracellular matrix production.

Effects of matrix gene mutations on surface motility were visualized through swarming plates. All mutants affected in matrix synthesis tested were observed to swarm better than the wild type NDmed strain after $24 \mathrm{~h}$ of incubation on minimal B-medium. The mother colony (place of bacterial inoculation) for the $\operatorname{tas} A$, eps $A-O$, and ypq $P$ mutants was producing a very viscous and loose matrix. This suggests that all together the Tas $\mathrm{A}$ (amyloid-like fibers) with the exopolysaccharide synthesized (through the products of eps $A$ $O$ and $y p q P)$ are important for the cell interlock and the structural stability in a biofilm.

However, it is difficult to differentiate the importance of each gene individually on the biofilm structural formation on agar. Hence, submerged biofilms revealed how in the tas $A$ and eps $A-O$ mutants biofilm cells were clearly unbundled and unable to form structured biofilms (Figure 2). Submerged biofilm formed by the bslA mutant was not affected at all, and those formed by the cap and the ypqP mutants were quite less affected after $24 \mathrm{~h}$ of incubation. Such observation has been numerically confirmed by an estimation of the biovolume and the thickness of submerged biofilms formed for all NDmed mutants studied here, which are represented in Figure 5. Indeed, in this study the ypqP mutation had a less effect on submerged biofilm biovolume and thickness after $24 \mathrm{~h}$ of incubation, however, the effect was more drastic when compared to the wild type NDmed after $48 \mathrm{~h}$ of 
incubation [13]. Moreover, ypqP was slightly expressed after $24 \mathrm{~h}$ and strongly transcribed only after $48 \mathrm{~h}$ (our unpublished data). This could suggest that ypqP is involved in the late structural biofilm spatial organization.

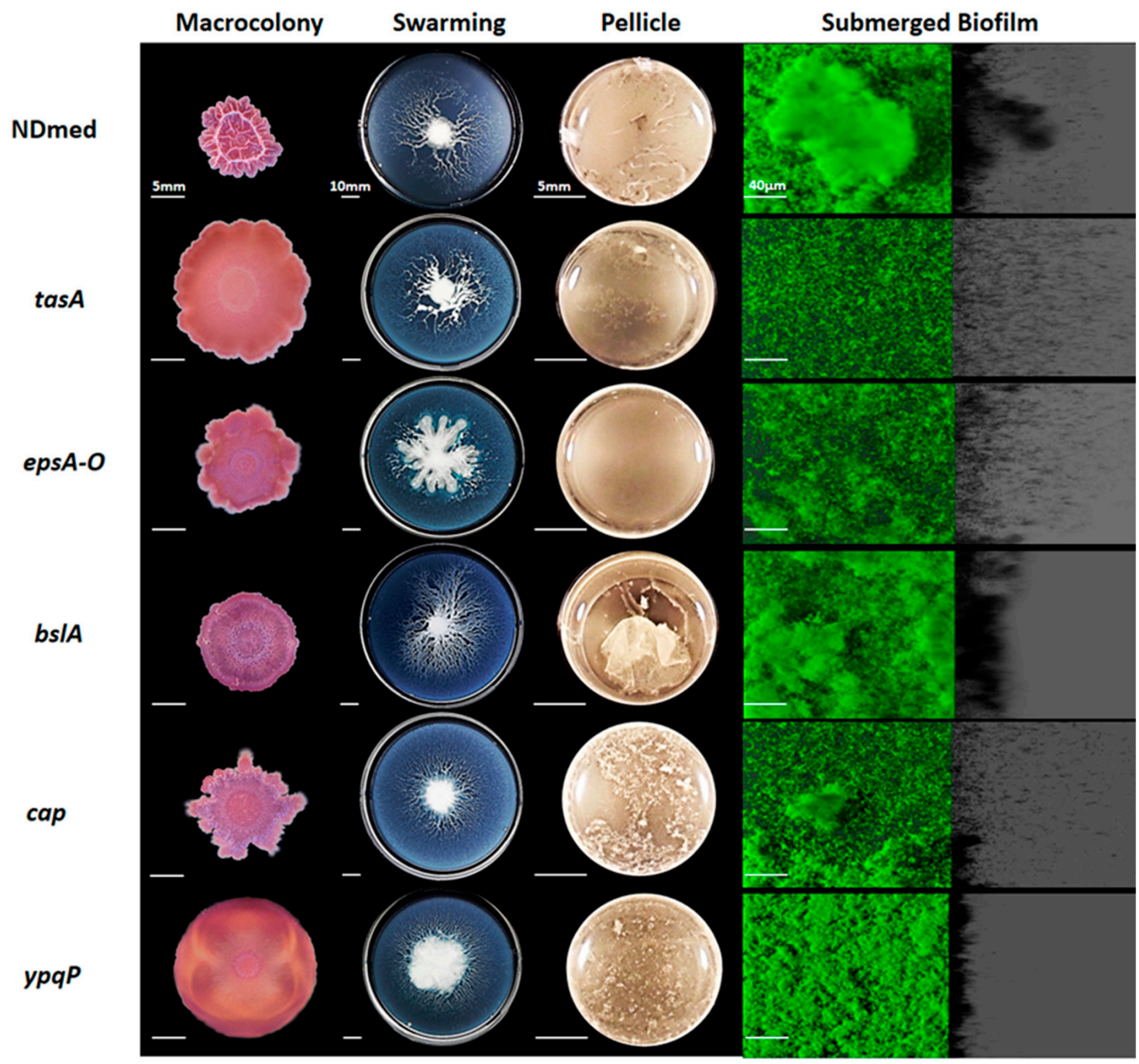

Figure 2. Different B. subtilis NDmed mutants of genes involved in extracellular matrix production on different culture assays. On $1.5 \%$ TSA, macrocolonies grown for 6 days at $30^{\circ} \mathrm{C}$ after a central spot of $3 \mu \mathrm{L}$ of an overnight bacterial culture in TSB. For swarming model, $2 \mu \mathrm{L}$ of bacterial culture $\left(10^{4}\right.$ bacterial dilution) have been inoculated on the middle of $0.7 \%$ B-medium plates and cultured for $24 \mathrm{~h}$ at $30^{\circ} \mathrm{C}$. In a 24-well plate, bacteria in TSB are cultured at $30{ }^{\circ} \mathrm{C}$ and pellicles were obtained after $24 \mathrm{~h}$. Macrocolony, swarming, and pellicle images are representative for the majority of the phenotype from at least three replicates for each strain revealing the effect of mutations on the biofilm formation. In a microplate system, immersed biofilms are labeled by SYTO 9 after $24 \mathrm{~h}$ on incubation at $30^{\circ} \mathrm{C}$. The shadow on the right represents the vertical projection of the submerged biofilm (scale bars represent $40 \mu \mathrm{m}$ ).

Regarding biofilms formed on liquid-air interface, our observations also highlight the importance of amyloid fibers and exopolysaccharides in the biofilm formation. In rich medium after $24 \mathrm{~h}$ of incubation the tas $A$ and eps $A-O$ mutants could form only very thin delicate pellicle (Figure 2), similar to what has been shown by previous studies on $B$. subtilis NCIB3610 [46,52]. As for the ypqP and cap mutants a less structured pellicle was formed. On the other hand, a delicate pellicle formed by the $b s l A$ mutant was very fragile and sensitive to any small plate movement, and sank to the bottom of the well due to cells lacking the hydrophobic layer that allows the pellicle to be stable at the air-liquid interface. These results suggest that tas $A$ and eps $A-O$ are crucial matrix genes, required 
in architectural settlement of $B$. subtilis multicellular communities in the different biofilm models. The genes cap, ypqP, and $b s l A$ also play an important role in formation of a highly structured and stable biofilm but in a more model-dependent way.

\subsection{Motility and Autolysins are Essentially Required for Architectural Submerged Biofilm Formation of B. subtilis NDmed}

In the mid-exponential growth phase of B. subtilis, two populations of cells were described: individual motile cells, and long chains of sessile cells [56]. Motility is a way for bacteria to colonize more favorable niches. Bacterial motility has also a positive role in nascent biofilm maturation and spreading, as it has been shown that motile cells can create transient pores that increase the nutrient flow in the matrix of mature biofilms [57]. In B. subtilis, flagellar motility studies have focused on both swarming over semi-solid agar plates and swimming in liquid culture $[27,28,56,58]$. As previously shown, B. subtilis hag mutants, affected in a gene encoding flagellin protein for flagellum formation, fail to swarm over different media tested including the B-medium $[27,29]$. In liquid culture, $B$. subtilis hag mutant was shown to have a delayed flagellar formation [10,58].

In Figure 3, the NDmed hag mutant formed a slightly wrinkled macrocolony on agar plate, while it failed to swarm on an optimal semi-solid plate. In static liquid culture after $24 \mathrm{~h}$ of incubation, this hag mutant was able to produce non-structured submerged compact biofilm with diminished thickness unaffecting the biovolume at the solid-liquid interface (Figure 5). Nevertheless, the hag mutant did not form pellicle at the air-liquid interface after $24 \mathrm{~h}$ of incubation in a rich medium (TSB). This suggested that the inability to swim prevented the cells to reach the air-liquid interface and thus inhibited or caused a delay in the formation of a pellicle, as previously observed [10].

For efficient growth and motility, bacteria need to continuously divide and adapt the cell wall composition (peptidoglycan), thanks to the autolysin system in B. subtilis. Expression of two major autolysin genes, $l y t F$ and $l y t C$ involved in cell separation is controlled by sigma factor $\mathrm{D}$ that also directs the transcription of motility and chemotaxis genes [24,59]. We have studied the effect of $l y t F$ and $l y t A B C$ mutation on the different assays of biofilm formation (Figure 3). The NDmed lytF mutants showed better aerial (macrocolony and pellicle) biofilm formation than the lyt $A B C$ autolysin mutant, that formed flat and pale color macrocolony (due to the reduced autolytic enzymes produced). However, in submerged biofilm, the $l y t F$ mutant was more affected and showed reduced biovolume (Figure 5A; $p<0.05$ ) while the biofilm biovolume of the lyt $A B C$ mutant was only slightly decreased. To look at the effect on motility, we have tested these mutant strains on swarming plates. Similarly to previous observation with B. subtilis NCIB3610 strain [59] the lytF mutant was able to swarm better than the lyt $A B C$ mutant, which led to the proposition that $l y t F$ is principally dedicated in cell separation and $l y t C$ is more involved in the proper flagellar function [59]. Hence, among the different autolysins, encoded by more than 35 genes encoding peptidoglycan hydrolases, inactivation of only one gene will have an impact on one of the biofilm models studied. However, absolute long chain cells phenotype could not be always seen, since different autolysins could replace each other $[24,60]$.

Interestingly, the $\operatorname{srf} A A$ mutation, affecting surfactin production and competence, has no effect on the structural biofilms developed as macrocolonies, pellicle, and submerged one (Figure 3) when compared to the wild type B. subtilis NDmed $(p>0.05)$. On swarming plates, surfactin production reduces surface tension during bacterial surface translocation. The 168 strain, carrying a frame-shift mutation in sfp, fails to produce surfactin and is thus unable to migrate over the B-medium swarming plate [27,29]. Moreover, studies with the NCIB3610 sfrAA mutant have also shown its inability to swarm [61]. However, either 168 or NCIB3610 srfAA mutants, have been shown to regain the ability of swarming, when provided with exogenous surfactin $[27,61]$. Interestingly, in our study, the NDmed $\operatorname{srf} A A$ mutant, which lacks a surfactin ring, displayed a monolayer dendritic swarming pattern having migrated from a more viscous mother colony, suggesting that other extracellular proteases have been secreted to facilitate the translocation. 


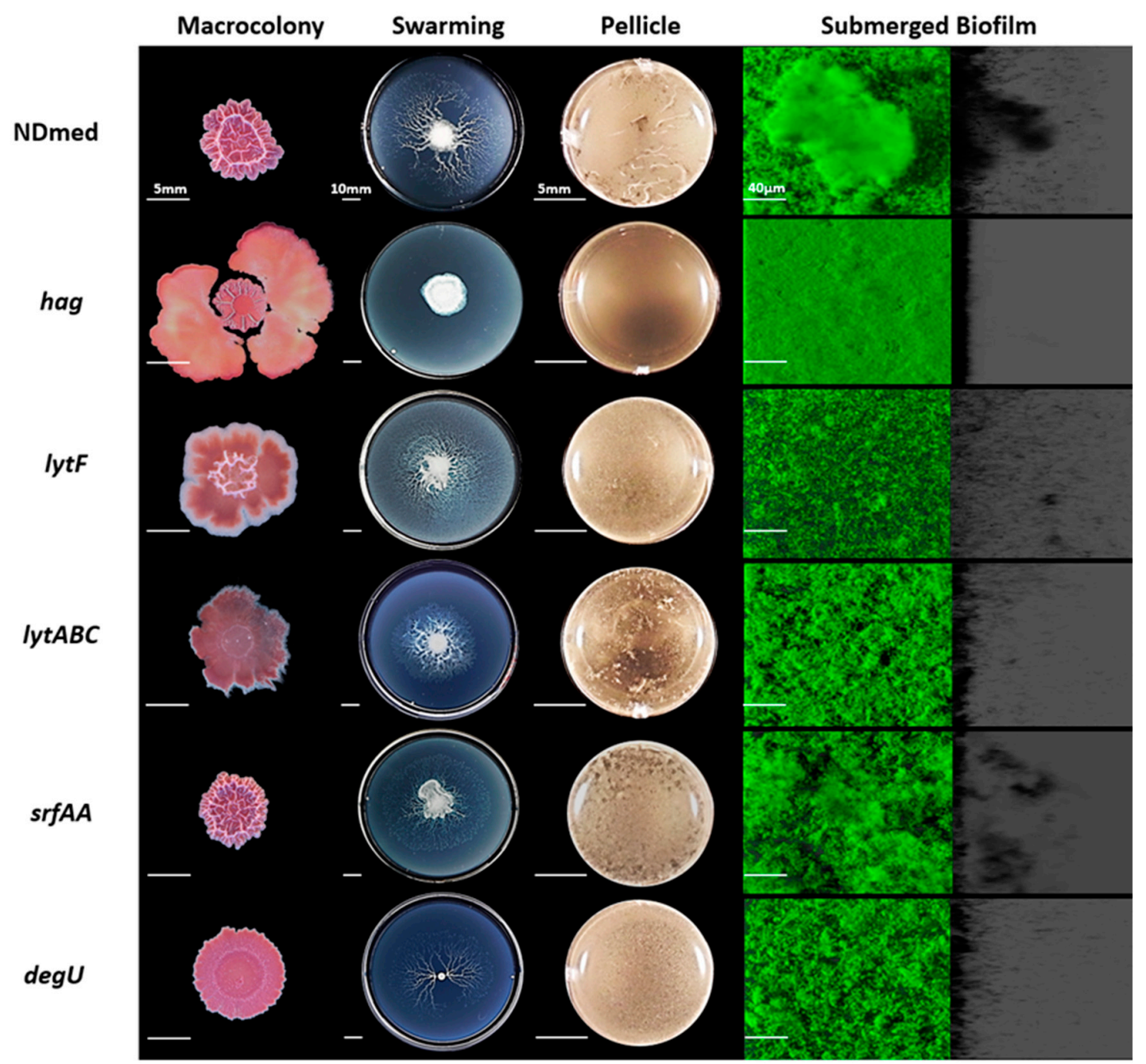

Figure 3. Motility and autolysin genes mutants of $B$. subtilis NDmed strain on different laboratory assays. Macrocolonies for mutated regulator genes are cultured on TSA for 6 days at $30^{\circ} \mathrm{C}$. Swarming plates are formed on B-synthetic medium $\left(0.7 \%\right.$ agar) that are cultured for $24 \mathrm{~h}$ at $30^{\circ} \mathrm{C}$. Pellicle and submerged biofilms were formed after $24 \mathrm{~h}$ of incubation at $30{ }^{\circ} \mathrm{C}$ in TSB medium. For submerged images the scale bars represent $40 \mu \mathrm{m}$. Macrocolony, swarming, and pellicle images are representative for the majority of the phenotype from at least three replicates for each strain revealing the effect of mutations on the biofilm formation.

Previous studies have shown that mutation of $\operatorname{deg} U$ affects transcription of more than 200 genes, which intervene in the genetic network activation for both flagellum and biofilm formation [54]. It has been demonstrated that different levels of DegU P co-ordinates $B$. subtilis multicellular behavior i.e., low level of $\operatorname{DegU} \sim \mathrm{P}$ activates swarming motility and complex architectural colony formation whereas high level of DegU P inhibits swarming and complex colony formation and is mainly required for the activation of exoprotease production [54,62]. In B. subtilis NCIB3610, DegU targets two proteins that have been shown to be involved in biofilm formation, YuaB (BslA) and YvcA (a putative membranebound lipoprotein). However, for the B. subtilis ATCC6051 strain, highly genetically similar to NCIB3610 (they are both descending from the original Marburg strain [37]), YvcA has been shown to be required only for complex colony formation but not for pellicle formation $[20,54,62]$. Hence, multicellular communities differ from strain to strain, which highlights the interest to test $\operatorname{deg} U$ mutation affecting the undomesticated strain NDmed and observe its effect over the different laboratory assays (Figure 3). Such degU mutation has a negative impact on the complex architectural macrocolony formed on agar surface and only slightly affects the biovolume formed by the submerged biofilm (Figure 5A, 
$p>0.05)$. A slight delay was observed in the swarming motility as well as for the pellicle formation indicating that a complex regulatory network, like phosphorylated Spo0A [20], intervenes to ensure a comparable biofilm formation.

\subsection{Mutation of B. subtilis NDmed Biofilm Regulators do Not Have the Same Impact on All Biofilm Models}

Spo0A, a key regulator of biofilm formation, is driven by exogenous and endogenous signals [63]. Activated Spo0A governs the genetic pathway controlling the matrix production gene expression by inducing $\operatorname{SinI}$ which binds and inhibits $\operatorname{SinR}$, a repressor of the eps and tapA-sipW-tas $A$ operons. Another role for Spo0A is to repress the expression of AbrB, a negative regulator for the initiation of biofilm formation $[8,64]$. Hence, the transition from surface-attached cells to three-dimensional biofilm structure is dependent on the activated Spo0A regulator [8]. To determine and clearly visualize the effect of these regulators on biofilm formation, $s p o 0 A, a b r B, \sin R, \sin I$, and $\operatorname{slr} R$ mutants of NDmed were tested under different biofilm culture conditions (Figure 4).

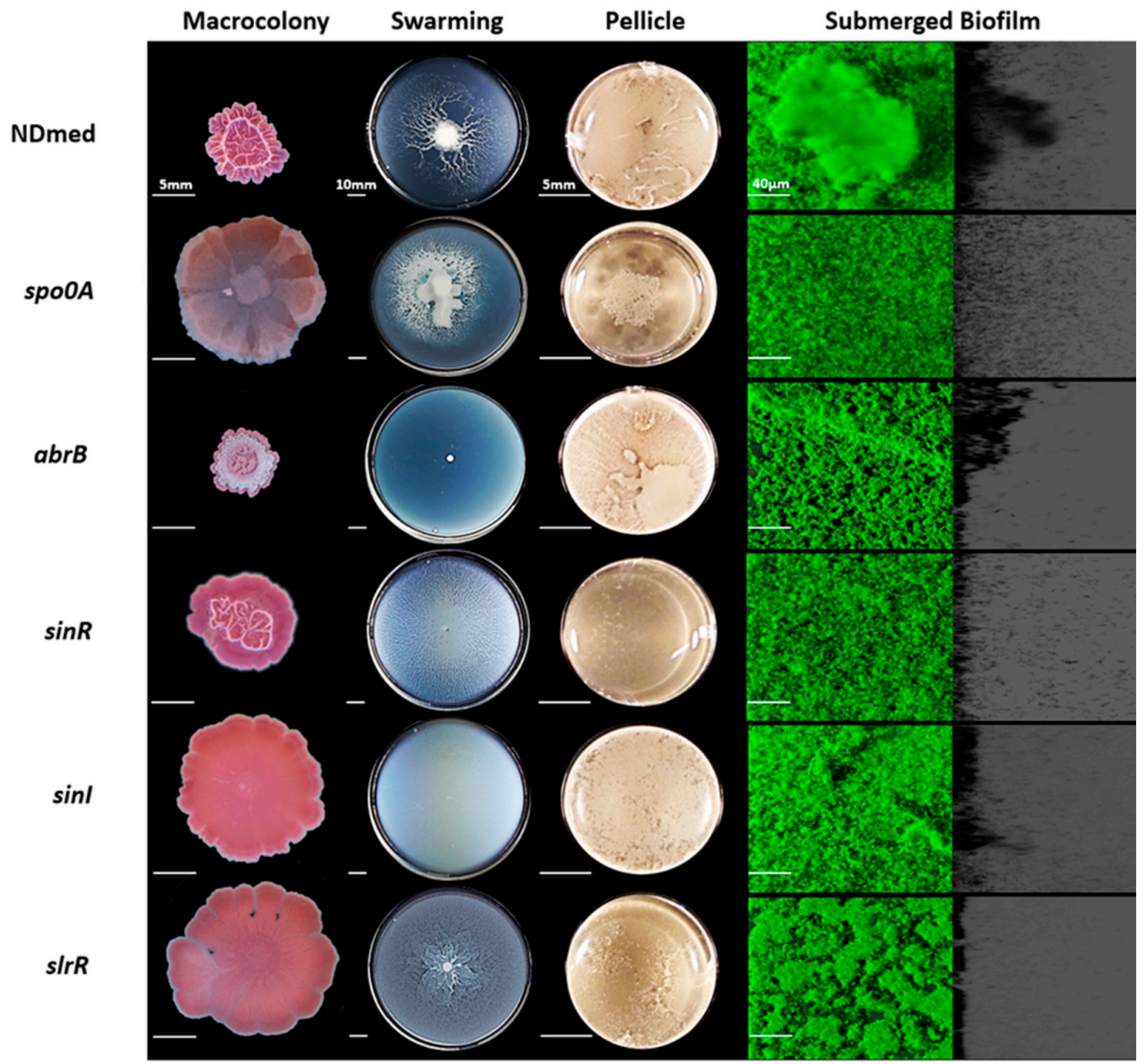

Figure 4. Mutational effect of global regulators required for biofilm development. Macrocolonies for mutants of regulator genes have been cultured on TSA for 6 days at $30^{\circ} \mathrm{C}$ after a central spot of $3 \mu \mathrm{l}$ of an overnight bacterial culture in TSB. Swarming plates are formed by B-synthetic medium $\left(0.7 \%\right.$ agar) incubated for $24 \mathrm{~h}$ at $30^{\circ} \mathrm{C}$. Pellicle formed after $24 \mathrm{~h}$ of incubation at $30^{\circ} \mathrm{C}$ in TSB medium. Macrocolony, swarming, and pellicle images are representative for the majority of the phenotype from at least three replicates for each strain revealing the effect of mutations on the biofilm formation. In a microplate system, immersed biofilms are labeled by SYTO 9 after $24 \mathrm{~h}$ on incubation at $30{ }^{\circ} \mathrm{C}$. The shadow on the right represents the vertical projection of the submerged biofilm (scale bars represent $40 \mu \mathrm{m}$ ). 
The spo0A mutant grew as a structureless spread macrocolony, while the $a b r B$ mutant showed a very vigorous and structured macrocolony on solid agar medium (Figure 4). In liquid culture, previous studies have shown that $B$. subtilis spoOA mutant cells were able to adhere to a surface and attach only as a monolayer form, suggesting that these mutants lack cell-cell interactions necessary for multicellular biofilm formation [8]. By using the CLSM, we could observe that the spo0A mutant cells did not form any thick submerged biofilm and rather remained essentially dispersed in the medium (Figure 4). These dispersed cells seemed to reach the surface of the liquid-air interface and form a highly disconnected pellicle-like structure in the middle of the well. On the other hand, the $a b r B$ mutant could form an extremely firm and highly structured pellicle, even more than that formed by the wild type NDmed strain, as well as thick highly structured architectural submerged biofilm (Figures 4 and $5 \mathrm{~B}$ ). Quantification of the submerged biofilm biovolumes (Figure 5A) formed by the spoOA and $a b r B$ mutants assures the role of Spo0A/AbrB pair as the main regulator for biofilm formation. On swarming plates, the $a b r B$ mutant was strongly affected, where even though producing an extensive surfactin zone, it was only able to form few small bud-like structures that emerged from the mother colony and then failed to proceed further. A similar behavior was observed for the $a b r B$ mutant of B. subtilis $(168 \mathrm{sfp}+)$ whose cells within the bud accumulate as long-chain forms [29]. Besides this, we could observe that the spo0A mutant on the swarming plates (Figure 4) showed extensive motility that filled all the plate rapidly with viscous multicellular biofilm formation in the middle of the plate. This could indicate that this viscous layer is due to an extensive secretion of surfactin or of extracellular proteases from a huge number of bacterial cells that lack cell-cell interaction, facilitating the movement over the surface.

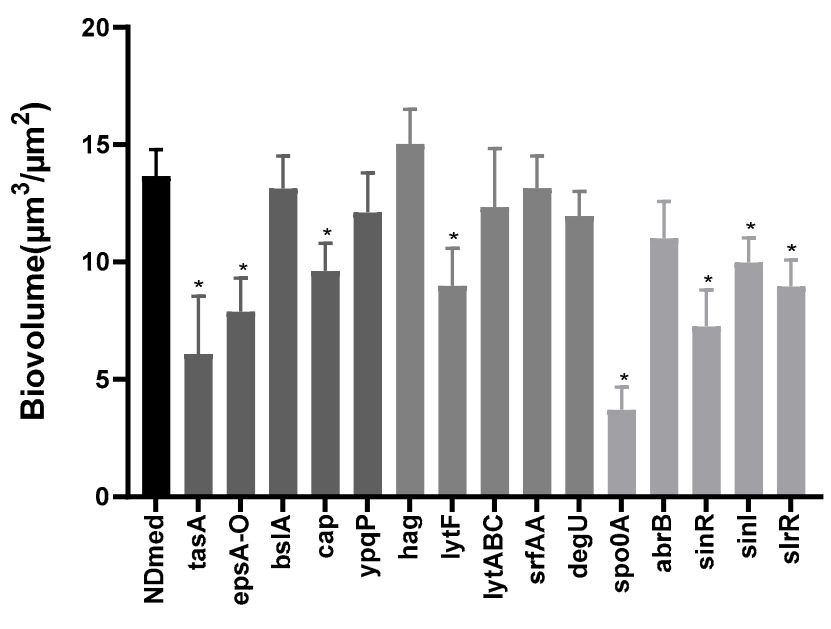

(A)

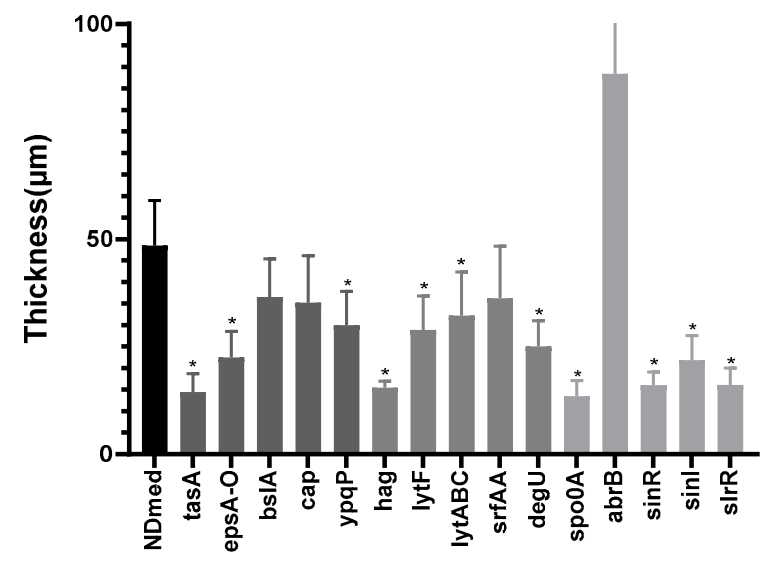

(B)

Figure 5. Submerged biofilms biovolumes and maximum thickness of the B. subtilis NDmed mutant strains studied. Biovolume (A) and maximum thickness (B) obtained were calculated from twenty confocal image series each. The color of the bars indicate gene categories (black for wild type NDmed, dark grey for matrix genes, grey for motility and autolytic genes, and light grey for global regulators). The error bars indicate the $95 \%$ confidence level, and the asterisk indicates the statistically significant differences $(*$ is for $p<0.05)$ with the NDmed wild-type strain.

Biofilm formation, under appropriate conditions, is initiated by motile B. subtilis cells that adhere to the surface become sessile and form long chains of non-motile cells, held together by extracellular matrix. The transcription factor SinR, a central regulator in the assembly of B. subtilis cells into multicellular communities [17], controls both motility and biofilm formation by directly repressing the eps and tapA-sipW-tas $A$ operons [65]. SinI, induced by phosphorylated Spo0A, binds directly to SinR and causes its inhibition. Moreover, SinI derepresses the action of SlrR $[18,66]$. SlrR, an additional regulatory protein, binds to and antagonizes SlrA, and thus constitutes a negative regulatory double loop with 
SinR, in which the slrR gene is repressed by $\operatorname{Sin} R$ and in turn SlrR prevents SinR from repressing slrR [16,67]. SlrA could play only a minor role in biofilm formation; however, it can be substituted functionally by SinI, its equivalent paralog [16,18]. Hence, SinR is inhibited by two paralogous antirepressors, SinI and SlrA [16].

A sinR mutation, in the NCIB3610 strain has been shown to lead to the formation of extremely thick colony when compared to the wild type, while $\sin I$ or $\operatorname{slr} R$ mutants formed flat structureless colonies on agar surface $[17,65]$. We have investigated the role of these major gene regulators on submerged biofilm formation and motility in the B. subtilis NDmed strain. Figure 4 shows similar phenotype for both $\sin I$ and $\operatorname{slr} R$ mutants with flat structureless macrocolonies on agar surface; however, the $\sin R$ mutant formed wrinkled macrocolony less structured than that formed by the wild type.

Swarming is a phenomenon taking place in two consecutive stages, migration over the surface of highly motile cells followed by their differentiation to less motile matrix producing cells that become stacked in a three-dimensional structure [26,68]. On swarming plates and after $24 \mathrm{hr}$ of incubation, the NDmed $\sin R$ mutant swarmed all over the plate with a multilayered biofilm dendritic pattern, which could indicate that swarming cells are unable to separate. In contrast, the NDmed sinI mutant eventually swarmed all over the plate in a monolayer form (Figure 4) similar to what has been described for sinI mutant in the NCIB3610 context [17]. This suggests that when matrix production genes are blocked, mutant bacterial strains were only able to reach the first stage of swarming. SlrR stimulates transcription of the tapA-sipW-tas $A$ operon but not of the eps operon and represses genes that mediate cell separation [10,18]. Thus, slrR mutation affects the expression of TasA but not Eps production and promotes cell separation. On swarming plates, the NDmed slrR mutant was able to swarm rapidly in a monolayer form all over the plate with less structured biofilm in the mother colony (place of inoculation) when compared to the wild type (Figure 4).

In liquid culture, a NDmed $\sin R$ mutant cultivated in TSB medium for $24 \mathrm{~h}$ of incubation, formed very thin pellicle (Figure 4). This could be due to cells unable to reach easily the surface. The NDmed sinI mutant was able to form a rather good pellicle, suggesting that the motile swimmer cells were able to reach the surface. These phenotypes are similar to what has been observed previously for ATCC6051 $\sin R$ and $\sin I$ mutant strains $[10,18]$. A defect in flagellar formation in the $\sin R$ mutant $[10,18]$ and a functional complementation between SinI and SlrA [16] in the sinI mutant could account for these phenotypes. Another hypothesis could be the occurrence of natural frameshift mutations within the $\sin R$ open reading frame, which suppress the blocking biofilm formation effects of a sinI mutation, as shown by Kearns et al. [17]. A NDmed slrR mutant could form a thin pellicle at the air-liquid interface, similarly to what has been observed in the NCIB3610 context [65].

The submerged biofilm biovolume of the NDmed $\sin R$ mutant (Figure 5A) was more negatively affected than that of the $\sin I$ or the $s l r R$ mutants when compared to the wild type NDmed (with a $p<0.05$ for these three mutated genes compared to the wild type). This could stress the importance of motility and autolysin in the formation of biofilm and suggest that mutation in one gene could be overcome and controlled by other regulatory pathways. Thus, these results further indicate that the SinI/SinR pair are the main regulators controlling the mode of bacterial life, motile or sessile, cells.

\section{Conclusions}

Overall, this study highlights the value of the NDmed strain as an undomesticated, naturally competent $B$. subtilis isolate, to point out the effect of gene mutation on the different structural biofilm communities formed. Gene mutation could exhibit a similar impact on all the different biofilm models formed on different culturing conditions. For instance, the tas $A$ and eps $A-O$ gene mutation affected all the surface associated communities formed but improved surface translocation. However, the $b s l A$ gene mutation has a negative effect just on the aerial biofilm models, structural microcolonies, and the pellicle stability, and no effect on the submerged biofilm formation. Our results emphasize the importance of 
the submerged model to further understand the molecular mechanisms during biofilm formation. Biofilm development throughout different environmental culturing conditions could have similar genetic profile, but these multicellular communities can also display considerable differences on the structural, chemical, and biological heterogeneity levels across different biofilm models. A whole transcriptional analysis could be done for the differently localized heterogeneous compartments of a biofilm to further understand the core of the transcriptional network that takes place between and during the biofilm development.

Author Contributions: Conceptualization, R.B., D.L.C., P.S.-V., Y.D. and K.H.; methodology, Y.D., P.S.-V., and J.D.; formal analysis, Y.D.; writing—original draft preparation, Y.D.; writing-review and editing, R.B., K.H., D.L.C., A.B., P.S.-V. and J.D.; supervision, R.B. and K.H.; funding acquisition, K.H. and R.B. All authors have read and agreed to the published version of the manuscript.

Funding: Yasmine Dergham is the recipient of fundings from the Union of Southern Suburbs Municipalities of Beirut, INRAE, Campus France PHC CEDRE 42280PF and Fondation AgroParisTech.

Data Availability Statement: Not applicable.

Acknowledgments: We thank Arnaud Chastanet, Etienne Dervyn, Michal Obuchowski, Nicola R. Stanley-Wall, and Roberto Kolter for providing strains, and the MIMA2 INRAE imaging platform for microscopic analysis.

Conflicts of Interest: The authors declare no conflict of interest.

\section{References}

1. Shapiro, J.A. Thinking about bacterial populations as multicellular organisms. Annu. Rev. Microbiol. 1998, 52, 81-104. [CrossRef]

2. Vlamakis, H.; Chai, Y.; Beauregard, P.B.; Losick, R.; Kolter, R. Sticking together: Building a biofilm the Bacillus subtilis way. Nat. Rev. Microbiol. 2013, 11, 157-168. [CrossRef]

3. Kearns, D.B. A field guide to bacterial swarming motility. Nat. Rev. Microbiol. 2010, 8, 634-644. [CrossRef] [PubMed]

4. Verstraeten, N.; Braeken, K.; Debkumari, B.; Fauvart, M.; Fransaer, J.; Vermant, J.; Michiels, J. Living on a surface: Swarming and biofilm formation. Trends Microbiol. 2008, 16, 496-506. [CrossRef] [PubMed]

5. Lemon, K.P.; Earl, A.M.; Vlamakis, H.C.; Aguilar, C.; Kolter, R. Biofilm Development with an Emphasis on Bacillus subtilis. Curr. Top. Microbiol. Immunol. 2008, 322, 1-16. [CrossRef] [PubMed]

6. Nagórska, K.; Bikowski, M.; Obuchowski, M. Multicellular behaviour and production of a wide variety of toxic substances support usage of Bacillus subtilis as a powerful biocontrol agent. Acta Biochim. Pol. 2007, 54, 495-508. [CrossRef]

7. Jamal, M.; Ahmad, W.; Andleeb, S.; Jalil, F.; Imran, M.; Nawaz, M.A.; Hussain, T.; Ali, M.; Rafiq, M.; Kamil, M.A. Bacterial biofilm and associated infections. J. Chin. Med. Assoc. 2018, 81, 7-11. [CrossRef]

8. Hamon, M.A.; Lazazzera, B.A. The sporulation transcription factor Spo0A is required for biofilm development in Bacillus subtilis. Mol. Microbiol. 2002, 42, 1199-1209. [CrossRef]

9. Stanley, N.R.; Lazazzera, B.A. Defining the genetic differences between wild and domestic strains of Bacillus subtilis that affect poly- $\gamma$-dl-glutamic acid production and biofilm formation. Mol. Microbiol. 2005, 57, 1143-1158. [CrossRef] [PubMed]

10. Kobayashi, K. Bacillus subtilis Pellicle Formation Proceeds through Genetically Defined Morphological Changes. J. Bacteriol. 2007, 189, 4920-4931. [CrossRef]

11. Bridier, A.; Le Coq, D.; Dubois-Brissonnet, F.; Thomas, V.; Aymerich, S.; Briandet, R. The Spatial Architecture of Bacillus subtilis Biofilms Deciphered Using a Surface-Associated Model and In Situ Imaging. PLoS ONE 2011, 6, e16177. [CrossRef] [PubMed]

12. Hamon, M.A.; Stanley, N.R.; Britton, R.A.; Grossman, A.D.; Lazazzera, B.A. Identification of AbrB-regulated genes involved in biofilmformation by Bacillus subtilis. Mol. Microbiol. 2004, 52, 847-860. [CrossRef] [PubMed]

13. Sanchez-Vizuete, P.; Le Coq, D.; Bridier, A.; Herry, J.M.; Aymerich, S.; Briandet, R. Identification of ypqP as a new Bacillus subtilis biofilm determinant that mediates the protection of Staphylococcus aureus against antimicrobial agents in mixed-species communities. Appl. Environ. Microbiol. 2015, 81, 109-118. [CrossRef]

14. Ostrov, I.; Sela, N.; Belausov, E.; Steinberg, D.; Shemesh, M. Adaptation of Bacillus species to dairy associated environment facilitates their biofilm forming ability. Food Microbiol. 2019, 82, 316-324. [CrossRef] [PubMed]

15. Chu, F.; Kearns, D.B.; Branda, S.S.; Kolter, R.; Losick, R. Targets of the master regulator of biofilm formation in Bacillus subtilis. Mol. Microbiol. 2006, 59, 1216-1228. [CrossRef] [PubMed]

16. Chai, Y.; Kolter, R.; Losick, R. Paralogous antirepressors acting on the master regulator for biofilm formation in Bacillus subtilis. Mol. Microbiol. 2009, 74, 876-887. [CrossRef]

17. Kearns, D.B.; Chu, F.; Branda, S.S.; Kolter, R.; Losick, R. A master regulator for biofilm formation by Bacillus subtilis. Mol. Microbiol. 2004, 55, 739-749. [CrossRef]

18. Kobayashi, K. SlrR/SlrA controls the initiation of biofilm formation in Bacillus subtilis. Mol. Microbiol. 2008, 69, 1399-1410. [CrossRef] 
19. Murray, E.J.; Kiley, T.B.; Stanley-Wall, N.R. A pivotal role for the response regulator DegU in controlling multicellular behaviour. Microbiology 2009, 155, 1-8. [CrossRef]

20. Verhamme, D.T.; Murray, E.J.; Stanley-Wall, N.R. DegU and Spo0A Jointly Control Transcription of Two Loci Required for Complex Colony Development by Bacillus subtilis. J. Bacteriol. 2008, 191, 100-108. [CrossRef] [PubMed]

21. Márquez-Magaña, L.M.; Chamberlin, M.J. Characterization of the sigD transcription unit of Bacillus subtilis. J. Bacteriol. 1994, 176, 2427-2434. [CrossRef] [PubMed]

22. Marquez, L.M.; Helmann, J.D.; Ferrari, E.; Parker, H.M.; Ordal, G.W.; Chamberlin, M.J. Studies of $\sigma(D)$-dependent functions in Bacillus subtilis. J. Bacteriol. 1990, 172, 3435-3443. [CrossRef]

23. Serizawa, M.; Yamamoto, H.; Yamaguchi, H.; Fujita, Y.; Kobayashi, K.; Ogasawara, N.; Sekiguchi, J. Systematic analysis of SigD-regulated genes in Bacillus subtilis by DNA microarray and Northern blotting analyses. Gene 2004, 329, 125-136. [CrossRef]

24. Margot, P.; Pagni, M.; Karamata, D. Bacillus subtilis 168 gene lytF encodes a $\gamma$-D-glutamate-meso-diaminopimelate muropeptidase expressed by the alternative vegetative sigma factor, $\sigma$ D. Microbiology 1999, 145, 57-65. [CrossRef] [PubMed]

25. Ostrowski, A.; Mehert, A.; Prescott, A.; Kiley, T.B.; Stanley-Wall, N.R. YuaB Functions Synergistically with the Exopolysaccharide and TasA Amyloid Fibers to Allow Biofilm Formation by Bacillus subtilis. J. Bacteriol. 2011, 193, 4821-4831. [CrossRef] [PubMed]

26. Harshey, R.M. Bacterial Motility on a Surface: Many Ways to a Common Goal. Annu. Rev. Microbiol. 2003, 57, 249-273. [CrossRef] [PubMed]

27. Julkowska, D.; Obuchowski, M.; Holland, I.B.; Séror, S.J. Comparative Analysis of the Development of Swarming Communities of Bacillus subtilis 168 and a Natural Wild Type: Critical Effects of Surfactin and the Composition of the Medium. Society 2005, 187, 65-76. [CrossRef]

28. Julkowska, D.; Obuchowski, M.; Holland, I.B.; Séror, S.J. Branched swarming patterns on a synthetic medium formed by wild-type Bacillus subtilis strain 3610: Detection of different cellular morphologies and constellations of cells as the complex architecture develops. Microbiology 2004, 150, 1839-1849. [CrossRef]

29. Hamze, K.; Julkowska, D.; Autret, S.; Hinc, K.; Nagorska, K.; Sekowska, A.; Holland, I.B.; Séror, S.J. Identification of genes required for different stages of dendritic swarming in Bacillus subtilis, with a novel role for phrC. Microbiology 2009, 155, 398-412. [CrossRef]

30. Bridier, A.; Sanchez-Vizuete, M.d.P.; Le Coq, D.; Aymerich, S.; Meylheuc, T.; Maillard, J.-Y.; Thomas, V.; Dubois-Brissonnet, F.; Briandet, R. Biofilms of a Bacillus subtilis Hospital Isolate Protect Staphylococcus aureus from Biocide Action. PLoS ONE 2012, 7, e44506. [CrossRef]

31. Martin, D.; Denyer, S.; McDonnell, G.; Maillard, J.-Y. Resistance and cross-resistance to oxidising agents of bacterial isolates from endoscope washer disinfectors. J. Hosp. Infect. 2008, 69, 377-383. [CrossRef]

32. Abe, K.; Kawano, Y.; Iwamoto, K.; Arai, K.; Maruyama, Y.; Eichenberger, P.; Sato, T. Developmentally-Regulated Excision of the SP $\beta$ Prophage Reconstitutes a Gene Required for Spore Envelope Maturation in Bacillus subtilis. PLoS Genet. 2014, 10, e1004636. [CrossRef] [PubMed]

33. Marmur, J. A procedure for the isolation of deoxyribonucleic acid from micro-organisms. J. Mol. Biol. 1961, 3, 208-218. [CrossRef]

34. Anagnostopoulos, C.; Spizizen, J. Requirements for Transformation in Bacillus subtilis. J. Bacteriol. 1961, 81, 741-746. [CrossRef]

35. Borenstein, S.; Ephrati-Elizur, E. Spontaneous release of DNA in sequential genetic order by Bacillus subtilis. J. Mol. Biol. 1969, 45, 137-152. [CrossRef]

36. Antelmann, H.; Engelmann, S.; Schmid, R.; Sorokin, A.; Lapidus, A.; Hecker, M. Expression of a stress- and starvation-induced $d p s /$ pexB-homologous gene is controlled by the alternative sigma factor $\sigma(\mathrm{B})$ in Bacillus subtilis. J. Bacteriol. 1997, 179, 7251-7256. [CrossRef] [PubMed]

37. Zeigler, D.R.; Prágai, Z.; Rodriguez, S.; Chevreux, B.; Muffler, A.; Albert, T.; Bai, R.; Wyss, M.; Perkins, J.B. The Origins of 168, W23, and Other Bacillus subtilis Legacy Strains. J. Bacteriol. 2008, 190, 6983-6995. [CrossRef]

38. Bidnenko, V.; Nicolas, P.; Grylak-Mielnicka, A.; Delumeau, O.; Auger, S.; Aucouturier, A.; Guérin, C.; Repoila, F.; Bardowski, J.; Aymerich, S.; et al. Termination factor Rho: From the control of pervasive transcription to cell fate determination in Bacillus subtilis. PLoS Genet. 2017, 13, e1006909. [CrossRef]

39. Monteferrante, C.G.; MacKichan, C.; Marchadier, E.; Prejean, M.-V.; Van Dijl, J.M.; Carballido-López, R. Mapping the twin-arginine protein translocation network of Bacillus subtilis. Proteomics 2013, 13, 800-811. [CrossRef]

40. Nagórska, K.; Hinc, K.; Strauch, M.A.; Obuchowski, M. Influence of the $\sigma B$ Stress Factor and yxaB, the Gene for a Putative Exopolysaccharide Synthase under $\sigma B$ Control, on Biofilm Formation. J. Bacteriol. 2008, 190, 3546-3556. [CrossRef] [PubMed]

41. Crutz, A.M.; Steinmetz, M. Transcription of the Bacillus subtilis sacX and sacY genes, encoding regulators of sucrose metabolism, is both inducible by sucrose and controlled by the DegS-DegU signalling system. J. Bacteriol. 1992, 174, 6087-6095. [CrossRef] [PubMed]

42. Murray, E.J.; Stanley-Wall, N.R. The sensitivity of Bacillus subtilis to diverse antimicrobial compounds is influenced by Abh. Arch. Microbiol. 2010, 192, 1059-1067. [CrossRef]

43. Dervyn, E.; Poncet, S.; Klier, A.; Rapoport, G. Transcriptional regulation of the cryIVD gene operon from Bacillus thuringiensis subsp. israelensis. J. Bacteriol. 1995, 177, 2283-2291. [CrossRef] [PubMed]

44. Bridier, A.; Dubois-Brissonnet, F.; Boubetra, A.; Thomas, V.; Briandet, R. The biofilm architecture of sixty opportunistic pathogens deciphered using a high throughput CLSM method. J. Microbiol. Methods 2010, 82, 64-70. [CrossRef] [PubMed] 
45. Friedman, L.; Kolter, R. Genes involved in matrix formation in Pseudomonas aeruginosa PA14 biofilms. Mol. Microbiol. 2003, 51, 675-690. [CrossRef]

46. Romero, D.; Aguilar, C.; Losick, R.; Kolter, R. Amyloid fibers provide structural integrity to Bacillus subtilis biofilms. Proc. Natl. Acad. Sci. USA 2010, 107, 2230-2234. [CrossRef]

47. Kiersztyn, B.; Siuda, W.; Chróst, R. Coomassie Blue G250 for Visualization of Active Bacteria from Lake Environment and Culture. Pol. J. Microbiol. 2017, 66, 365-373. [CrossRef]

48. Neumann, U.; Khalaf, H.; Rimpler, M. Quantitation of electrophoretically separated proteins in the submicrogram range by dye elution. Electrophoresis 1994, 15, 916-921. [CrossRef]

49. Branda, S.S.; González-Pastor, J.E.; Ben-Yehuda, S.; Losick, R.; Kolter, R. Fruiting body formation by Bacillus subtilis. Proc. Natl. Acad. Sci. USA 2001, 98, 11621-11626. [CrossRef] [PubMed]

50. McLoon, A.L.; Guttenplan, S.B.; Kearns, D.B.; Kolter, R.; Losick, R. Tracing the Domestication of a Biofilm-Forming Bacterium. J. Bacteriol. 2011, 193, 2027-2034. [CrossRef]

51. Branda, S.S.; González-Pastor, J.E.; Dervyn, E.; Ehrlich, S.D.; Losick, R.; Kolter, R. Genes Involved in Formation of Structured Multicellular Communities by Bacillus subtilis. J. Bacteriol. 2004, 186, 3970-3979. [CrossRef] [PubMed]

52. Branda, S.S.; Chu, F.; Kearns, D.B.; Losick, R.; Kolter, R. A major protein component of the Bacillus subtilis biofilm matrix. Mol. Microbiol. 2006, 59, 1229-1238. [CrossRef] [PubMed]

53. Kobayashi, K.; Iwano, M. BslA(YuaB) forms a hydrophobic layer on the surface of Bacillus subtilis biofilms. Mol. Microbiol. 2012, 85, 51-66. [CrossRef]

54. Kobayashi, K. Gradual activation of the response regulator DegU controls serial expression of genes for flagellum formation and biofilm formation in Bacillus subtilis. Mol. Microbiol. 2007, 66, 395-409. [CrossRef] [PubMed]

55. Yu, Y.; Yan, F.; Chen, Y.; Jin, C.; Guo, J.-H.; Chai, Y. Poly- $\gamma$-Glutamic Acids Contribute to Biofilm Formation and Plant Root Colonization in Selected Environmental Isolates of Bacillus subtilis. Front. Microbiol. 2016, 7, 1811. [CrossRef]

56. Kearns, D.B.; Losick, R. Cell population heterogeneity during growth of Bacillus subtilis. Genes Dev. 2005, 19, 3083-3094. [CrossRef] [PubMed]

57. Houry, A.; Gohar, M.; Deschamps, J.; Tischenko, E.; Aymerich, S.; Gruss, A.; Briandet, R. Bacterial swimmers that infiltrate and take over the biofilm matrix. Proc. Natl. Acad. Sci. USA 2012, 109, 13088-13093. [CrossRef]

58. Hölscher, T.; Bartels, B.; Lin, Y.-C.; Gallegos-Monterrosa, R.; Price-Whelan, A.; Kolter, R.; Dietrich, L.E.P.; Kovács, Á.T. Motility, Chemotaxis and Aerotaxis Contribute to Competitiveness during Bacterial Pellicle Biofilm Development. J. Mol. Biol. 2015, 427, 3695-3708. [CrossRef]

59. Chen, R.; Guttenplan, S.B.; Blair, K.M.; Kearns, D.B. Role of the $\sigma$ D-dependent autolysins in Bacillus subtilis population heterogeneity. J. Bacteriol. 2009, 191, 5775-5784. [CrossRef]

60. Smith, T.J.; Foster, S.J. Characterization of the involvement of two compensatory autolysins in mother cell lysis during sporulation of Bacillus subtilis 168. J. Bacteriol. 1995, 177, 3855-3862. [CrossRef]

61. Kearns, D.B.; Chu, F.; Rudner, R.; Losick, R. Genes governing swarming in Bacillus subtilis and evidence for a phase variation mechanism controlling surface motility. Mol. Microbiol. 2004, 52, 357-369. [CrossRef] [PubMed]

62. Verhamme, D.T.; Kiley, T.B.; Stanley-Wall, N.R. DegU co-ordinates multicellular behaviour exhibited by Bacillus subtilis. Mol. Microbiol. 2007, 65, 554-568. [CrossRef] [PubMed]

63. Mielich-süss, B.; Lopez, D. Molecular mechanisms involved in Bacillus subtilis biofilm formation. Environ. Microbiol. 2015 17, 555-565. [CrossRef] [PubMed]

64. Strauch, M.; Webb, V.; Spiegelman, G.; Hoch, J.A. The Spo0A protein of Bacillus subtilis is a repressor of the abrB gene. Proc. Natl. Acad. Sci. USA 1990, 87, 1801-1805. [CrossRef] [PubMed]

65. Takada, H.; Morita, M.; Shiwa, Y.; Sugimoto, R.; Suzuki, S.; Kawamura, F.; Yoshikawa, H. Cell motility and biofilm formation in Bacillus subtilis are affected by the ribosomal proteins, S11 and S21. Biosci. Biotechnol. Biochem. 2014, 78, 898-907. [CrossRef]

66. Chu, F.; Kearns, D.B.; McLoon, A.; Chai, Y.; Kolter, R.; Losick, R. A novel regulatory protein governing biofilm formation in Bacillus subtilis. Mol. Microbiol. 2008, 68, 1117-1127. [CrossRef]

67. Chai, Y.; Kolter, R.; Losick, R. Reversal of an epigenetic switch governing cell chaining in Bacillus subtilis by protein instability. Mol. Microbiol. 2010, 78, 218-229. [CrossRef]

68. Copeland, M.F.; Weibel, D.B. Bacterial swarming: A model system for studying dynamic self-assembly. Soft Matter 2009, 5, 1174-1187. [CrossRef] [PubMed] 